Çukurova Üniversitesi Mühendislik Fakültesi Dergisi, 36(2), ss. 493-507, Haziran 2021

Cukurova University Journal of the Faculty of Engineering, 36(2), pp. 493-507, June 2021

\title{
Akış Kontrolü Uygulanan Açık Bir Kavitede Akış Karakteristikleri ve Isı Geçişinin Sayısal Olarak İncelenmesi
}

\author{
İrem DALGIÇ ${ }^{* 1}$, Nehir TOKGÖZ1 ${ }^{1}$ Coşkun ÖZALP ${ }^{1}$ \\ ${ }^{1}$ Osmaniye Korkut Ata Üniversitesi, Mühendislik Fakültesi, Enerji Sistemleri Mühendisliği \\ Bölümü, Osmaniye
}

Geliş tarihi: 06.05.2021 Kabul tarihi: 30.06 .2021

$\ddot{\mathbf{O} z}$

Kavite akışı, geometrik olarak basit bir yapıya sahip olmasına rağmen farklı akış özelliklerini içerisinde bulunduran bir akış tipidir. Bu akış yapısındaki değişimler, kavite içerisinde 1sı transferinin iyileştirilmesini sağlayabilmektedir. Sunulan bu çalışmada, iki boyutlu, açık kavite içerisinde 7 farklı konuma (C1, C2, C3, C4, C7, C9 ve C11 silindir konumları) yerleştirilen silindirin akış yapısı ve 1sı transfer üzerindeki etkileri sayısal olarak incelenmiştir. Silindir çap1 $0,025 \mathrm{~m}$, kavitenin uzunluk ve derinlik oranı (D/L) 2 ve silindir çapı ile tanımlanan Reynolds sayısı 10000 olarak belirlenmiştir. Isı transfer analizi için kavite duvarlarına sabit 1sı akısı ( $\left.\dot{\mathrm{q}}=10000 \mathrm{~W} / \mathrm{m}^{2}\right)$ uygulanmıştır. Sayısal analizlerde akışkan olarak su seçilip, çözümlemeler sonlu hacimler yöntemini ile yapılmıştır. Akış yapısı ve 1sı transfer sonuçları kavite içerisinde silindirin bulunmadığı durum ile mukayese edilmiştir. Elde edilen sonuçlar silindirin kullanılmadığ 1 boş kavite akışına kıyasla kavite içerisinde farklı konumlara yerleştirilen dairesel bir silindir kullanılmasının akış yapısını değiştirdiğini ve Nusselt sayısında artış meydana getirdiğini göstermiştir.

Anahtar Kelimeler: Akış kontrolü, Hesaplamalı akışkanlar dinamiği (HAD), Kavite akışı, Sabit silindir

\section{Numerical Investigation of Flow Characteristics and Heat Transfer in an Open Cavity with Flow Control}

\begin{abstract}
The cavity flow, despite its geometrically simple structure, contains various fluid flow properties. The flow structure change inside the cavity provides to enhance the heat transfer. In this study, the flow structure of 7 different cylinders located in different positions (C1, C2, C3, C4, C7, C9 and C11 cylinder locations) in an open cavity and its heat transfer effects are investigated in two dimensional. The diameter of the cylinder is $0.025 \mathrm{~m}$, the ratio of the depth and the length is $\mathrm{D} / \mathrm{L}=2$ and the Reynolds number is 10000 based on the cylinder diameter. For the heat transfer analysis, a constant heat flux is applied to the cavity walls $(\dot{\mathrm{q}}=10000$ $\mathrm{W} / \mathrm{m}^{2}$ ). Water is the chosen liquid, and finite volume method is used for the numerical analysis. Flow structure and heat transfer results are compared with the cavity which has no embedded cylinders inside. The obtained results reveal that using a circular cylinder located in different locations inside the cavity changes the flow structure and increases the Nusselt number compared to the empty cavity case.
\end{abstract}

Keywords: Flow control, CFD, Cavity flow, Constant cylinder

*Sorumlu yazar (Corresponding author): İrem DALGIÇ, irem.dlgc@outlook.com 


\section{GíRiș}

Kavite akışları katı yüzeylerdeki boşluklar üzerinden geçen akışı aerodinamik ve aeroakustik olarak inceleyen, akışkanlar mekaniğinin temel konularından biridir. Günümüzde gerek askeri gerekse de endüstriyel uygulamalarda kavite yapılarına rastlamak mümkündür. Bunlara örnek olarak elektronik soğutma, solar kolektörler, uçak iniş takımları ve savaş uçaklarının füze yuvaları gibi çeşitli mühendislik uygulamalarında verilebilir. Bugüne kadar yapılan pek çok çalışmada kavite akışının doğası, Reynolds sayısına, akışın sınır tabaka özelliklerine (Laminar veya türbülanslı sınır tabaka) ve kavite geometrisine bağlı olarak değiştiği gözlemlenmiştir.

Kavitenin geometrik özellikleri olan uzunluk (L), derinlik (D) ve genişlik (W) olarak ifade edilen karakteristik boyutların oranları (L/D ve L/W) kavite geometrisinin sinıflandırılmasindaki temel parametrelerdir. Genel olarak kaviteler uzunluk ve derinlik oranlarına göre (L/D) "Açık" ve "Kapalı" kaviteler şeklinde sınıflandırılmaktadır [1]. Kayma tabakasının kavite ön ve arka duvarları arasında oluşturduğu akış yapısı sınıflandırmanın yapılmasında önemli bir rol oynamıştır Charwat ve arkadaşları [2]. Kavitenin geometrik özelliklerine bağlı olarak oluşan bir diğer parametre iki boyutlu ve üç boyutlu kavite akışlarıdır. İki boyutlu kavite akışında, akış üniform ve tüm kavite genişliği boyunca tutarlı bir kayma tabakası oluşturmaktadır. Ancak üç boyutlu kavite akışlarında kavite genişliği azaldıkça kavite duvarlarının ve köşelerinin giderek baskın hale gelmesi sonucunda kayma tabakası tutarlılığını koruyamamaktadır. $\mathrm{Bu}$ yüzden $\mathrm{L} / \mathrm{W}<1$ olduğunda akışın kavite genişliğinin büyük bir kısmında iki boyutlu göründüğü, L/W>1 olduğunda ise, akışın gittikçe daha fazla üç boyutlu hale geldiği belirlenmiştir Ahuja ve Mendoza [3]. Akışın kavite içerisinde gösterdiği kararsız yapı ile beraberinde oluşan salınımlar kavite akıșının sınıflandırılması haricinde yoğun periyodik salınımlara, kayma tabakası kararsızlıklarına ve ısı transfer çalışmaları açısından oldukça dikkat çekici sonuçlar ortaya koymaktadir.

Kanal içerisine yerleştirdikleri değişken uzunluk ve derinlik oranına sahip kavitede meydana gelen isı transferini Haugen ve Dhanak [4] deneysel ve analitik olarak incelemişlerdir. Kavite duvarına ayrı ayrı sabit sıcaklık ve sabit 1sı akısı uygulamış ve her iki durum için sonuçları kıyaslamışlardır. Sıcaklık gradyanlarının kayma tabakası bölgeleri. Kavite duvarına uygulanan sabit sıcaklık ve sabit 1s1 akıs1 için elde edilen sonuçlar arasında pek bir fark olmadığını ortaya koymuşlardır. Benzer bir çalışma olarak Yamamoto ve arkadaşları [5] sabit 1s1 akıs1 ile alt duvarı 1sıtılmış olan kavitelerin uzunluğu sabit tutulurken değişen uzunluk ve derinlik oranlarının 1si transferleri üzerindeki etkisini deneysel olarak incelenmişlerdir. Çok sı̆̆ kavitelerin üst yüzeylerindeki akışın alt yüzeylerdeki akışa yeniden bağlanmasının derin kavitelere nispeten isı transferini daha fazla etkilediğini gözlemlemişlerdir. Pereira ve Sousa [6] tek bir uzunluk ve derinlik oranı için sı ğ ve açık bir kavite ele almışlardır. Çalışmalarının sonucunda kavite üzerinde belirlenen farklı konumlardaki ortalama hız değerleri ile deneysel verilerden elde edilen hız değerlerinin birbirleriyle uyum içerisinde olduğu sonucuna varmışlardır. Güneş kollektörlerinin etrafına yerleştirilen dik rüzgâr bariyerlerinin konveksiyon etkisi üzerinden yola çıkarak kollektör ile bariyer arasında oluşan kaviteyi, geniş uzunluk ve derinlik oranına sahip sığ kaviteler olarak inceleyen Zdanski ve arkadaşları [7], akış dinamiği ile konveksiyona etki eden parametreleri belirlemişlerdir. Konveksiyona etkisi açısından baktıklarında dış akışın kavite içerisinde oluşturduğu girdapların konveksiyonu inhibe ettiğini ve bu durumun laminer akışta ve türbülanslı akışın düşük Reynolds sayılarında meydana geldiği sonucuna ulaşmışlardır. Ashcroft ve Zhang [8] açık kavitenin kayma tabakasındaki türbülanslı akış yapılarının zaman ortalamasına ve anlık gelişimi üzerinde akış hızının ve geometri yapısının etkilerini araştırmışlardır. Kavitenin zaman ortalamalı akış yapısında kayma tabakasının, geometri şeklinden ve hızdan etkilenmediği sonucuna varmışlardır. Santrifüj fan ile hava akışının sağlandığı bir rüzgâr tüneli içerisine yerleştirdikleri açık kavite üzerinden geçen akış1 inceleyen Faure ve arkadaşları [9] kavite yüksekliği sabit kalacak şekilde kavite uzunluğunu kademeli olarak değiştirerek akışı Parçacık Görüntülemeli Hız Ölçüm Tekniği (PIV) ile görüntülemişlerdir. Türbülanslı kavite akışları ile kendi kendine devam 
eden salınımlardan sorumlu büyük ölçekli girdap yapılarının nicel özelliklerini Sung ve Kang [10] PIV ve Uygun Ortogonal Ayrıştırma analizi (POD) kullanarak araştırmışlardır. Aynı Reynolds sayısı için kavitenin uzunluk ve derinlik oranındaki artışın kavite ön duvarına yakın konumda ikincil bir girdap yapısı oluşturduğunu belirlemişlerdir. Özalp ve arkadaşları [11] uzunluk ve derinlik oranı sabit üçgen, dikdörtgen ve yarı dairesel kavitelerden geçen akışı Parçacık Görüntülemeli $\mathrm{H} 1 z$ Ölçüm yöntemini kullanarak incelemişlerdir. Artan Reynolds sayılarında girdap merkezlerinin dikdörtgen kavitede kavite merkezine doğru, üçgen ve yarı dairesel kavitelerde sağa doğru genişleyerek ilerleme meydana getirdiğini göstermişlerdir. Kavitenin kapak bölümünde maksimum Reynolds gerilmeleri ve türbülans şiddeti değerlerini gözlemlemiş olup, dikdörtgen ve üçgen kaviteler yarı dairesel kavite şekline göre çok daha büyük türbülansa neden olduğu sonuca varmışlardır. Özsoy ve Aslan [12] kavite içerisinde oluşan çevrinti (girdap) yapılarının akış ayrılmasından itibaren kavite uzunluğu boyunca artarak, kavite arka duvarında yüksek seviyelere ulaştığını gözlemlemişlerdir Dikdörtgen bir kavitenin sığ ve derin olduğu durumları sayısal simülasyon kullanarak girdap yapılarını inceleyen Wahba [13] çalışmasında, üst duvarı hareketli olan sığ ve derin kavitelerin değişen uzunluk ve derinlik oranlarının ve Reynolds sayılarının akış yapısına etkisini incelenmiştir. Sı ̆̆ kavitede Reynolds sayısı artıkça simetrik girdap yapısının kaybolduğunu, kavitenin sol alt köşesindeki köşe girdabının, asimetrik olarak büyüyerek ikincil bir girdap yapısı oluşturduğu sonucuna varmıştır. DanXun ve arkadaşları [14] açık bir kaviteden geçen akışın Reynolds sayısı ile arasındaki ilişkinin sayısal olarak incelemişlerdir. Düşük Reynolds sayısında kavite içerisinde saat yönünde dönen birincil girdap ve saat yönünün tersine dönen ikincil girdap yapisı gözlemlemişlerdir. Artan Reynolds sayısı ile birincil girdap yapısı genişleyerek yukarı akışa taşınırken, ikincil girdap yapısının yukarı akış bölgesine doğru daha yerel hale geldiğini ve belirli bir Reynolds sayısı değerinden sonra girdap yapılarında değişikliğin ihmal edilebilir olduğunu belirlemişlerdir. Birincil girdap yapısı ile Reynolds geriliminin benzer korelasyonlar gösterdiğini ve yüksek seviyelerde Reynolds gerilmesinin arka duvarın önünde yoğun momentum değişimi meydana getirdiği sonucuna varmışlardır. Selimefendigil ve Öztop [15] nanoakışkan ile dolu olan kapalı kare kavite içerisine yerleştirdikleri bir silindirin akış ve 1S1 transferi üzerindeki etkisini araştırmışlardır. Richardson sayısı, Hartmann sayısı, silindirin dönme hızı ve nanopartikülün hacim konsantrasyonunun 1s1 transfer üzerindeki etkisini incelemişledir. Richardson sayısının ve konsantrasyonunun artmasının 1sı transferinde artış meydana getirdiğini fakat Hartmann sayısının artışının 1sı transferini olumsuz etkileyerek azalmasına sebep olduğunu gözlemlemişlerdir. Silindirin sabit kaldığı duruma kıyasla saat yönünün tersine dönmesinin oluşturduğu kayma tabakası kararsızlıklarından dolayı 1sı transferinde artış sağladığını belirlemişlerdir. Madi [16] sı̆̆ bir kavite üzerindeki sınır tabaka akışının Reynolds sayısı ve türbülans yoğunluğundaki değişimin ve duvar jeti akışındaki nozul yüksekliğinin 1s1 transferine etkisini sayısal olarak incelenmiştir. Akış, sınır tabaka akışı için gözlemlediğinde yeniden bağlanma uzunluğunun ve sıcak akışkan tabaka kalınlığının Reynolds sayısındaki artıştan çok türbülans yoğunluğundaki artıştan etkilendiği sonucuna varmışlardır. Reynolds sayısı ve türbülans yoğunluğu hızından Nusselt sayısındaki artışı değerlendirdiğinde durumun tam tersi olduğunu Reynolds sayısındaki artışın sonuçlara daha fazla etki ettiğini belirlemiştir. Maksimum 1s1 transferinin, yeniden bağlanma bölgesinin önünde, ana devridaim bölgesinde gerçekleştiğini ortaya koymuştur. Kavite derinliğinin nozul yüksekliğine oranın artmasıyla birlikte Nusselt sayısının arttığını ve 1sı transferinin kavite zemininde artış gösterdiği sonucuna varmıştır.

Literatürde açık kavite akışlarının, akış yapısı ve 1sı transfer analizleri üzerine sayısal ve deneysel pek çok çalışma bulunmaktadır. Fakat açık kavitenin mevcut akış yapısını değiştiren ve bu değişimin 1sı transfer üzerindeki etkisini inceleyen sayısal çalışmalara pek rastlanmamıştır. Bu çalışmanın amacı açık bir kavite içerisinde 7 farklı konuma yerleştirilen silindirin akış yapısında meydana getirdiği değişimlerin, 1sı transfer üzerinde yapmış olduğu etkiyi incelemektir. Sonuçların doğrulanmasından sonra silindirin kavite içerisinde farklı konumlarda olmasının akış yapısına ve 1sı 
transferine etkilerinin sayısal çalışması gerçekleştirilmiştir.

\section{MATERYAL VE METOT}

\subsection{Modelin Tanımlanması}

Çalışmada incelenen kavite geometrisi ANSYS Desing Moduler programında iki boyutlu olarak tasarlanmıştır. Çalışma boyunca sabit kavite ölçüleri içerisinde 7 farklı konuma silindir yerleştirilerek ve silindirin bulunmadığ 1 boş kavite akışı olarak tanımlanan durum için sayısal analiz gerçekleştirilmiştir. Şekil 1'de görüldüğü gibi kavitenin uzunluğu (D) $0,2 \mathrm{~m}$, derinliği (L) $0,1 \mathrm{~m}$ ve silindirin çapı 0,025 m'dir. Kanal girişi ile kavite ön duvarı arasındaki ve kanal çıkışı ile kavite arka duvarı arasındaki mesafeler 0,55 m uzunluğundadır. Kanalın üst duvarı ile kavite tabanı arasındaki mesafe $0,25 \mathrm{~m}$ olarak belirlenmiştir. Kavite geometrisi $\mathrm{x}$ ekseni doğrultusunda $0,55 \mathrm{~m}$, y ekseni doğrultusunda 0,1 m uzaklıkta tanımlanmıştır ve kavite içerisindeki sıcaklık, hız, akım çizgisi ve girdap dağılımları $\mathrm{x}$ ekseni doğrultusunda $0,55 \mathrm{~m}$ ile $0,75 \mathrm{~m}$, y ekseni doğrultusunda $-0,1 \mathrm{~m}$ ile $+0,05 \mathrm{~m}$ aralıklarında incelenmiştir.

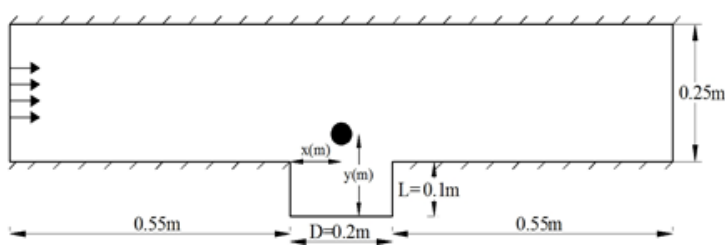

Şekil 1. Kavitenin şematik gösterimi ve model ölçüleri

Silindir, kavite içerisine merkezi olarak yerleştirilmiştir ve bulunduğu konumlar, silindir merkezinin kavite duvarlarına olan mesafesine göre C1, C2, C3, C4, C7, C9 ve C11 konumları şeklinde adlandırılmıştır. Çizelge 1 'de bu konumlara ait silindir merkezinin bulunduğu koordinatlar (x (m), y (m)) verilmiştir. C1, C2 ve C3 konumlarında silindir, kavite ön ve arka duvarlarına eşit uzaklıkta olacak şekilde konumlandırılmıştır. Silindir merkezi C1 konumundan $\mathrm{C} 3$ konumuna kadar yatay doğrultuda $\mathrm{x}(\mathrm{m})=0,65$ m'de düşey doğrultuda ise $0,05 \mathrm{~m}$ aralıklarla kavite tabanına doğru yerleştirilmiştir. C4 ve $\mathrm{C} 7$ konumları kavite ön duvarına $0,05 \mathrm{~m}$ mesafe olacak şekilde y ekseni doğrultusunda $0,05 \mathrm{~m}$ aralıklarla konumlandırılmışlardır. $\mathrm{C} 9$ ve $\mathrm{C} 11$ konumları kavite arka duvarına $0,025 \mathrm{~m}$ ve $0,05 \mathrm{~m}$ uzaklık olacak şekilde yerleştirilmişlerdir.

Çizelge 1. Yerleştirilen silindirin koordinatları

\begin{tabular}{|l|c|c|}
\hline Konumlar & $\mathbf{x}(\mathbf{m})$ & $\mathbf{y}(\mathbf{m})$ \\
\hline C1 Konumu & 0,65 & 0,05 \\
\hline C2 Konumu & 0,65 & 0 \\
\hline C3 Konumu & 0,65 & $-0,05$ \\
\hline C4 Konumu & 0,6 & $-0,05$ \\
\hline C7 Konumu & 0,6 & 0 \\
\hline C9 Konumu & 0,7 & $-0,05$ \\
\hline C11 Konumu & 0,725 & 0 \\
\hline
\end{tabular}

\subsection{Modelin Sınır Şartları}

- Akışkanın hesaplama bölgesine girişine "hız girişi”" ve çıkışına "basınç çıkışı" sınır şartları tanımlanmıştır. Girişte hız girişte üniform $0,4 \mathrm{~m} / \mathrm{s}$, çıkışta ise basınç atmosfer basınc1 $1 \mathrm{~atm}$ olarak belirlenmiştir. Silindirin açık bir kanal içerisine yerleştirilerek incelendiğini göstermek amacıyla kanalın üst duvarı akışkan hızı ve yönü ile aynı olacak şekilde hız girişi sınır şartı olarak tanımlanmıştır.

- Kavite yüzeyleri "sabit duvar (çeper)" sınır şartı ile tanımlanmışlardır. Kavite yüzeylerindeki duvar sınır şartlarına termal sınır koşulu olarak $10000 \mathrm{~W} / \mathrm{m}^{2}$ sabit 1s1 akısı uygulanmıştır.

- Silindir yüzeyine hiçbir termal sınır şartı tanımlanmamıştır.

\subsection{Sayısal Metot ve Denge Denklemleri}

Akış ve sıcaklık alanlarına ait zamana bağlı denklemlerin sayısal çözümlemesi ANSYS-Fluent programı ile gerçekleştirilmiştir. $\mathrm{Bu}$ çalışmada süreklilik denklemlerinin akış ve sıcaklık alanlarını oluşturulan sonsuz küçük kontrol hacimlerine kısmi diferansiyel denklemler şekilde uygulanmasını sağlayan sonlu hacimler metodu kullanılmıştır. Navier Stokes Denklemleri, zamana bağlı, iki boyutlu, türbülanslı bir akış için sayısal olarak çözümlenmiştir. Momentum ve enerji denklemlerini ayrıştırmada ikinci mertebeden ileri gidişli şema (second order upwind scheme), basınç-hız bağıntısı için SIMPLE algoritması kullanılmıştır. Yakınsama 
kriteri enerji için $10^{-8}$, diğer tüm bağımlı değişkenler için ise $10^{-6}$ olarak uygulanmıştır. Kavite içerisindeki silindirin akış üzerindeki etkilerinin gözlemlenebilmesi için Courant sayısı 5 alınarak en uygun zaman adımı 0,06 saniye olarak belirlenmiştir ve hesaplanan zaman adımı akış içerisindeki değişimlerin gözlemlenmesi için yeterli olmuştur. Çözümlemesi yapılan süreklilik denklemi Eşitlik 1, momentum denklemi Eşitlik 2 ve enerji denklemi Eşitlik 3'te verilmiştir.

$\frac{\partial \rho}{\partial t}+\nabla \cdot(\rho \mathrm{V})=0$

$\frac{\partial u_{i}}{\partial t}+\frac{\partial\left(u_{i} u_{j}\right)}{\partial x_{j}}=-\frac{1}{\rho} \frac{\partial p}{\partial x_{i}}+\frac{\partial}{\partial x_{j}}\left[v\left(\frac{\partial u_{i}}{\partial x_{j}}+\frac{\partial u_{j}}{\partial x_{i}}\right)-\overline{u_{i}^{\prime} u_{j}^{\prime}}\right]$

Burada $\rho$ akışkanın yoğunluğu, $u_{i}, x_{i}$ yönündeki ortalama hız bileşeni, $\mathrm{p}$ basınç, $\mu$ dinamik viskosite ve $u^{\prime}$ hızın çalkantı bileşenini temsil etmektedir. i ve $\mathrm{j}$ indisleri de her bir boyutu ( $\mathrm{i}=\mathrm{x}, \mathrm{y}, \mathrm{z}$ ve $\mathrm{j}=\mathrm{x}, \mathrm{y}$, z) göstermektedir (Eşitlik 3).

$\frac{\partial T}{\partial t}+\frac{\partial}{\partial x_{i}}\left(\rho u_{i} T\right)=\frac{\partial}{\partial x_{j}}\left[\left(\frac{\mu}{P r}+\frac{\mu_{t}}{P_{t}}\right) \frac{\partial T}{\partial x_{j}}\right]$

Burada $\mu_{t}$ turbülans viskozitesidir. Reynoldsortalamalı yaklaşım modeli (RANS) akış analizlerinde yaygın olarak kullanılmaktadır. Bu modelde türbülans stresi $-\rho \overline{u_{\imath}^{\prime} u_{\jmath}^{\prime}}$, nin de modellenmesi gerekir. Boussinesq hipotezi ile Eşitlik 4'deki gibi modellenebilir.

$-\rho \overline{u_{i}^{\prime} u_{j}^{\prime}}=\mu_{t}\left(\frac{\partial u_{i}}{\partial x_{j}}+\mu \frac{\partial u_{j}}{\partial x_{i}}\right)-\frac{2}{3}\left(\rho k+\mu \frac{\partial u_{i}}{\partial x_{i}}\right) \delta_{i j}$

Burada $\mathrm{k}$ türbülans kinetik enerjisidir ve $k=\frac{1}{2} \overline{u_{\imath}^{\prime} u_{\jmath}^{\prime}}$ ile tarif edilir. Çalışmada küçük girdap yapılarını doğrudan çözümlemek yerine, bu yapıları modelleyen ve daha az eleman sayısına sahip ağ yapısı ile çalışma imkânı sağlayan Reynolds Ortalamalı Navier Stokes (RANS) Denklemleri ve standart k- $\varepsilon$ türbülans modeli tercih edilmiştir.

$\frac{\partial}{\partial t}\left(\rho u_{i}\right)+\frac{\partial}{\partial x}\left(\rho u_{i} u_{j}\right)=\frac{\partial p}{\partial x_{i}}+\frac{\partial}{\partial x_{j}}\left[\mu\left(\frac{\partial u_{i}}{\partial x_{j}}+\frac{\partial u_{j}}{\partial x_{i}}-\frac{2}{3} \delta_{i j} \frac{\partial u_{k}}{\partial x_{k}}\right)\right]$ $+\frac{\partial}{\partial x_{j}}\left(-\rho \overline{u_{i}^{\prime} u_{j}^{\prime}}\right)$
Eşitlik 5'de Reynold Ortalamalı Navier Stokes Denkleminin kartezyen tensör formu verilmiştir. $\left(-\rho \overline{u_{i}^{\prime} u_{j}^{\prime}}\right)$ ifadesi modellenecek olan Reynolds gerilim tensörü olarak adlandırılmaktadır. Denklemdeki " $\delta_{i j}$ " ifadesine Kronecker deltası adı verilmektedir Doğan [17].

$$
\frac{\partial(\bar{\rho} \mathrm{k})}{\partial \mathrm{t}}+\frac{\partial\left(\bar{\rho} \widetilde{\mathrm{u}}_{\mathrm{j}} \mathrm{k}\right)}{\partial \mathrm{x}_{\mathrm{j}}}=\frac{\partial}{\partial \mathrm{x}_{\mathrm{j}}}\left(\left(\mu+\frac{\mu_{\mathrm{t}}}{\sigma_{\mathrm{k}}}\right) \frac{\partial \mathrm{k}}{\partial \mathrm{x}_{\mathrm{j}}}\right)+\mu_{\mathrm{t}}\left(\frac{\partial \widetilde{\mathrm{u}}_{\mathrm{i}}}{\partial \mathrm{x}_{\mathrm{j}}}+\frac{\partial \widetilde{\mathrm{u}}_{\mathrm{j}}}{\partial \mathrm{x}_{\mathrm{i}}}\right) \frac{\partial \widetilde{\mathrm{u}}_{\mathrm{i}}}{\partial \mathrm{x}_{\mathrm{j}}}-\bar{\rho} \varepsilon
$$

$\frac{\partial(\bar{\rho} \varepsilon)}{\partial \mathrm{t}}+\frac{\partial\left(\bar{\rho} \tilde{\mathrm{u}}_{j} \varepsilon\right)}{\partial \mathrm{x}_{\mathrm{j}}}=\frac{\partial}{\partial \mathrm{x}_{\mathrm{j}}}\left(\left(\mu+\frac{\mu_{\mathrm{t}}}{\sigma_{\varepsilon}}\right) \frac{\partial \varepsilon}{\partial \mathrm{x}_{\mathrm{j}}}\right)+\mathrm{C}_{\varepsilon 1} \frac{\varepsilon}{\mathrm{k}} \mu_{\mathrm{t}}$

$\left(\frac{\partial \tilde{u}_{i}}{\partial \mathrm{x}_{j}}+\frac{\partial \tilde{u}_{j}}{\partial \mathrm{x}_{i}}\right) \frac{\partial \tilde{u}_{i}}{\partial \mathrm{x}_{j}}-\mathrm{C}_{\varepsilon 2} \bar{\rho} \frac{\varepsilon^{2}}{\mathrm{k}}$

Eşitlik 6 ve Eşitlik 7'de verilen " $\sigma_{k}$ " türbülans Prandtl sayısını ve " $\sigma_{\varepsilon}$ " model sabitini ifade etmektedir. Standart k- $\varepsilon$ modelinde, türbülans Eddy viskozitesi, $\mathrm{C}_{\mu}, \mathrm{C}_{\varepsilon 1}$ ve $\mathrm{C}_{\varepsilon 2}$ model katsayıları Eşitlik 8, Eşitlik 9 ve Eşitlik 10'da verilmişstir.

$\mu_{\mathrm{k}}=\bar{\rho} \mathrm{C}_{\mu} \frac{\mathrm{k}^{2}}{\varepsilon}$

$\mathrm{C}_{\mu}=\left(\frac{\mathrm{u}_{*}^{2}}{\mathrm{k}}\right)^{2}$

$\mathrm{C}_{\varepsilon 1}=\mathrm{C}_{\varepsilon 2^{-}} \frac{\mathrm{k}}{\sqrt{\mathrm{C}_{\mu}} \sigma_{\varepsilon}}$

$\operatorname{Re}=\frac{\mathrm{pxVxD_{ \textrm {h } }}}{\mu}$

Reynolds sayısını veren bağıntı Eşitlik 11'de gösterilmiştir Çengel ve arkadaşları [18]. Çalışmada Reynolds sayısı boş kavite akışı için kavite derinliği $\left(D_{h}=L\right)$ ile silindir konumları için ise silindir çapına $\left(D_{h}=d\right)$ göre tanımlanmıştır [18].

$\mathrm{Nu}_{\mathrm{x}}=\frac{\mathrm{h}_{\mathrm{x}} \mathrm{S}}{\mathrm{k}}$

Eşitlik 12'de yerel $\mathrm{Nu}$ sayısını veren bağıntı gösterilmiştir. " $h_{x}$ ", yerel 1sı transfer katsayıs1, "k" 1s1l iletkenlik katsayısı ve " $S$ " karakteristik uzunluktur. Çalışmada $\mathrm{Nu}$ sayısı " $N u$ " hidrolik çapa $\left(D_{h}=S\right)$ göre hesaplanmıştır Çengel ve arkadaşları [18]. 


\subsection{Ağdan Bağımsızlık}

Sayısal çalışmaların en önemli ayağını ağ yapısı oluşturmaktadır. Sonuçların ağ yapısına göre çok fazla değiştiği bilinen bir gerçektir. Bundan dolayı sonuçların ağ yapısından bağımsızlığını göstermek için beş farklı ağ yapısında çözümlemeler yapılmıştır. Ağ yapılarının sahip olduğu eleman sayılar1 sirasiyla 1545(1.),2571 (2.),3672 (3.), 14104 (4.) ve 32205(5.)'tir. Belirlenen eleman sayıları kullanılarak oluşturulan ağ yapılarına göre $\mathrm{x}=0,64 \mathrm{~m}$ deki hı dağılımları Sekil 2'de gösterilmiştir. 1. ve 3. ağ yapıları arasında eleman sayısı artıkça profilde çok büyük olmasa da değişiklikler meydana gelmiştir. 4. ve 5. ağ yapıları arasındaki farkın diğer eleman sayılarına göre oldukça az olduğu görülmektedir. Bu iki ağ yapısı arasındaki farkın az olmasından dolayı kavite için sayısal analizlerin nispeten daha az elaman sayısına (14104) sahip 4. ağ yapısı ile yapılmasına karar verişmiştir.

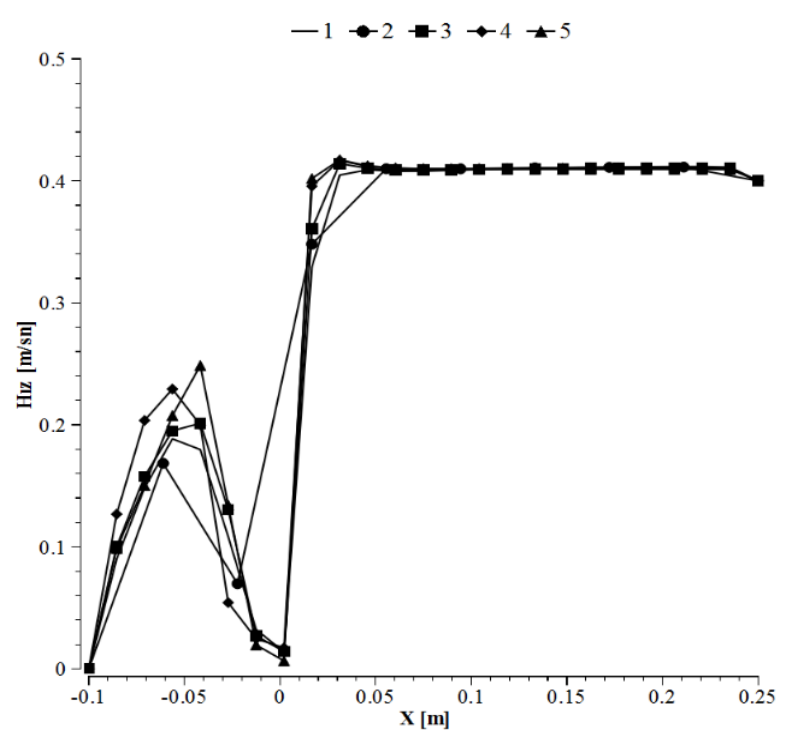

Şekil 2. Hız dağılımlarının ağ yapılara göre karşılaştırılması

Kavite ve silindir etrafına yapısal olmayan (unstructured) ağ uygulanmıştır. İyi bir çözüm elde etmek için türbülansın büyük bir kısmının ve diğer akış alanlarına nispeten yüksek hız ve basınç gradyanlarının oluşmasının beklendiği silindir etrafında daha sık ağ yapısı tercih edilmiştir.

\section{BULGULAR VE TARTIŞMA}

Kavite duvarlara sabit $1 \mathrm{~S} 1$ akıs $\left(\mathrm{q}=10000 \mathrm{~W} / \mathrm{m}^{2}\right)$ uygulanan açık kavite akışıını mevcut çalışmasında, 7 farklı konuma $(0,55 \leq \mathrm{x}(\mathrm{m}) \leq 0,75 \mathrm{~m}$, $-0,1 \mathrm{~m} \leq \mathrm{y}(\mathrm{m}) \leq 0,1 \mathrm{~m})$ yerleştirilmiş adyabatik bir silindirin akış yapısı ve 1 ș transfer üzerindeki etkileri sayısal olarak incelenmiștir. Sayısal simülasyon uzunluk-derinlik oran $(\mathrm{D} / \mathrm{L}) 2$ olan bir kavitede ve silindir çapı ile tanımlanan Reynolds sayıs1 10000 için gerçekleştirilmiştir. Kavitede silindirin farklı konumlarda olduğu durumlar, aynı Reynolds sayısı için kavitede silindirin olmadığı "Boş kavite" akışı olarak ifade edilen sonuç ile mukayese edilmiştir.

\subsection{Sonuçların Doğrulanması}

Literatürde yaygın olarak kullanılan ve kabul edilen denklemlerden yararlanılarak çalışmanın güvenirliği iki boyutlu, silindirsiz paralel iki plaka arasındaki sıkıştırılamaz, türbülanslı bir akış ile doğrulanmıştır. Kullanılan sayısal çözümleme kodunun doğruluğu Nusselt Sayısı için Dittus-Boelter ve Gnielinski eşitliğiyle Sürtünme Faktörü için ise DarcyWeisbarch ve Blasius Denklemleri ile mukayese edilmiştir Çengel ve arkadaşları. [18]. 


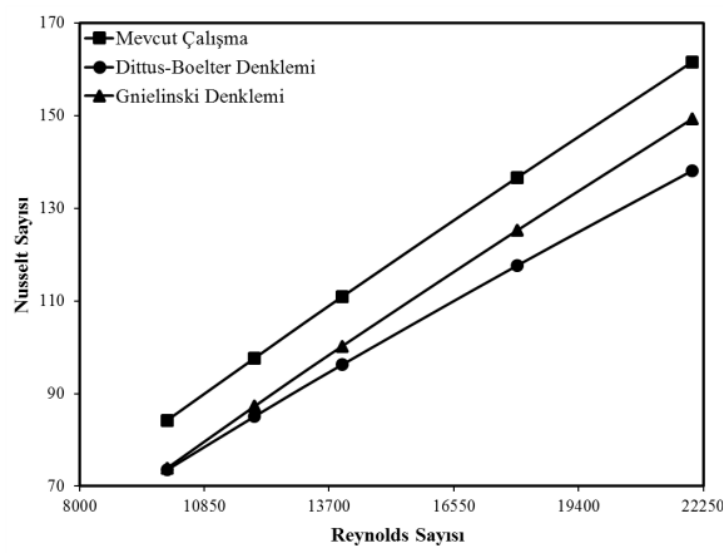

Şekil 3. Nusselt sayısının doğrulanması

Şekil 3'te görüldüğü gibi hesaplanan Nusselt sayısı ile Gnielinski ve Dittus-Boelter denklemleriyle elde edilen Nusselt sayıları arasında oldukça yakın sonuçlar elde edilmiştir. Elde edilen sonuçlar ile denklemlere göre hesaplanan sonuçlara arasında en az fark \%7 ile Gnielinski denklemiyle, en büyük fark ise \%14 ile Dittus-Boelter denklemiyle $\mathrm{Re}=22000$ 'de elde edilmiştir. Nusselt Sayısı bağıntılarında sayısal sonuçlar ile deneysel sonuçlar arasındaki farklılık \%5-20 aralığında olabileceği göz önünde bulundurulduğunda mevcut çalışmanın doğruluğunun oldukça güvenilir olduğu görülmektedir.

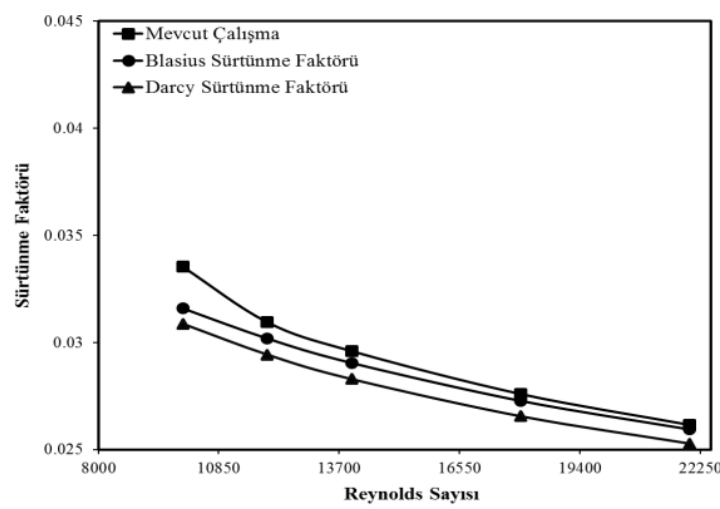

Şekil 4. Sürtünme faktörünün doğrulanması

Ayrıca sürtünme faktörlerinin karşılaştırılması ile de çözümün doğruluğu pekiştirilmiştir. Hesaplanan sürtünme faktörünün Blasius ve Darcy sürtünme faktörleri ile kıyaslanması Şekil 4'de verilmiştir. Minimum sapmanın Blasius Sürtünme Faktöründe
\%0,8 ile Reynolds Sayıs 22000 için, maksimum sapmanın ise \%8 ile Reynolds Sayısı 10000 için Darcy Sürtünme Faktöründe olduğu belirlenmiştir. Sonuç itibariyle mevcut çalışmada kullanılan sayısal çözümleme kodunun literatürde kabul görülen denklemler ile uyum içerisinde olması çalışmaya olan güvenirliği sağlamıştır

\subsection{Silindir Konumlarının Akış Yapısı Üzerine Etkisi}

\subsubsection{Ortalama x ve y Hızı Dağılımları}

Silindir konumlarının akış alanı içerisindeki ortalama $x$-hız ve y-hızı dağılımları Şekil 5'te verilmiştir ve şekillerin hangi konuma ait olduğu üzerlerinde belirtilmiştir.C1, C2 ve C3 konumlarında, gelen akış silindirin bulunduğu konumlar itibari ile enerjisini artırmış ve daha yüksek hızlarda kavite içerisine giriş yapmıştır. C1 konumunda akış yönü doğrultusunda silindirin alt ve üst yüzeylerinden geçen akış maksimum hıza ulaşmıştır ve özellikle kavite içerisine doğru yönlenen hız artışı boş kavite akışına göre kavite tabanına doğru güçlü ters akış yapısı oluşturmuştur. C2 konumunda kayma tabakas1 kavite ön duvarından ayrıldıktan hemen sonra silindirle etkileşime girdiği noktadan itibaren kavite tabanına doğru ilerlemiştir. Biri kavite ön duvarına diğeri kavite arka duvarına doğru olacak şekilde iki farklı ters akış meydana getirmiştir. Silindirin bulunduğu konum kayma tabakasında üretmiş olduğu kararsızlıklar haricinde kavite içerisindeki akışın uzaklaşmasında da etkili olmuştur. Kavite tabanına yakın ve kavite orta düzleminde yer alan C3 konumunda, gelen akış kavite ön duvarından ayrıldıktan hemen sonra silindirin üst yüzeyine yönelerek, kavite tabanına paralel kayma tabakası meydana getirmiştir. Kayma tabakasının, kavite arka duvarı ile etkileşimi sonucunda kavite tabanına yakın ters akış oluşturmuştur. Kavite ön ve arka duvarlarına yakın konumlarda bulunan $\mathrm{C} 4$ ve $\mathrm{C} 9$ konumları, boş kavite akışına göre kayma tabakasının hızını arttırmış ve akışın kavite arka duvarından kavite tabanına doğru silindiri de içerisine alan daha güçlü bir ters akış yapısı oluşmasını sağlamışlardır. C7 konumu kayma tabakasının silindirin ön yüzeyine temas ettikten sonra kavite tabanına yönlenmesi sonucunda C2 
konumunda olduğu gibi kavite içerisinde iki farklı ters akış meydana getirmiştir. C11 konumundaki akış yapısına bakıldığında, silindirin alt yüzeyinden geçen kayma tabakası boş kavite durumuna nispeten kavite uzunluğu boyunca daha güçlü ters akış yapısı oluşturmuştur. Silindir konumlarına ve boş kaviteye ait boyutsuz ortalama yatay $\left(\mathrm{v} / U_{\infty}\right)$ ve dikey $\left(u / U_{\infty}\right)$ hız profilleri Şekil 6'da verilmiştir.
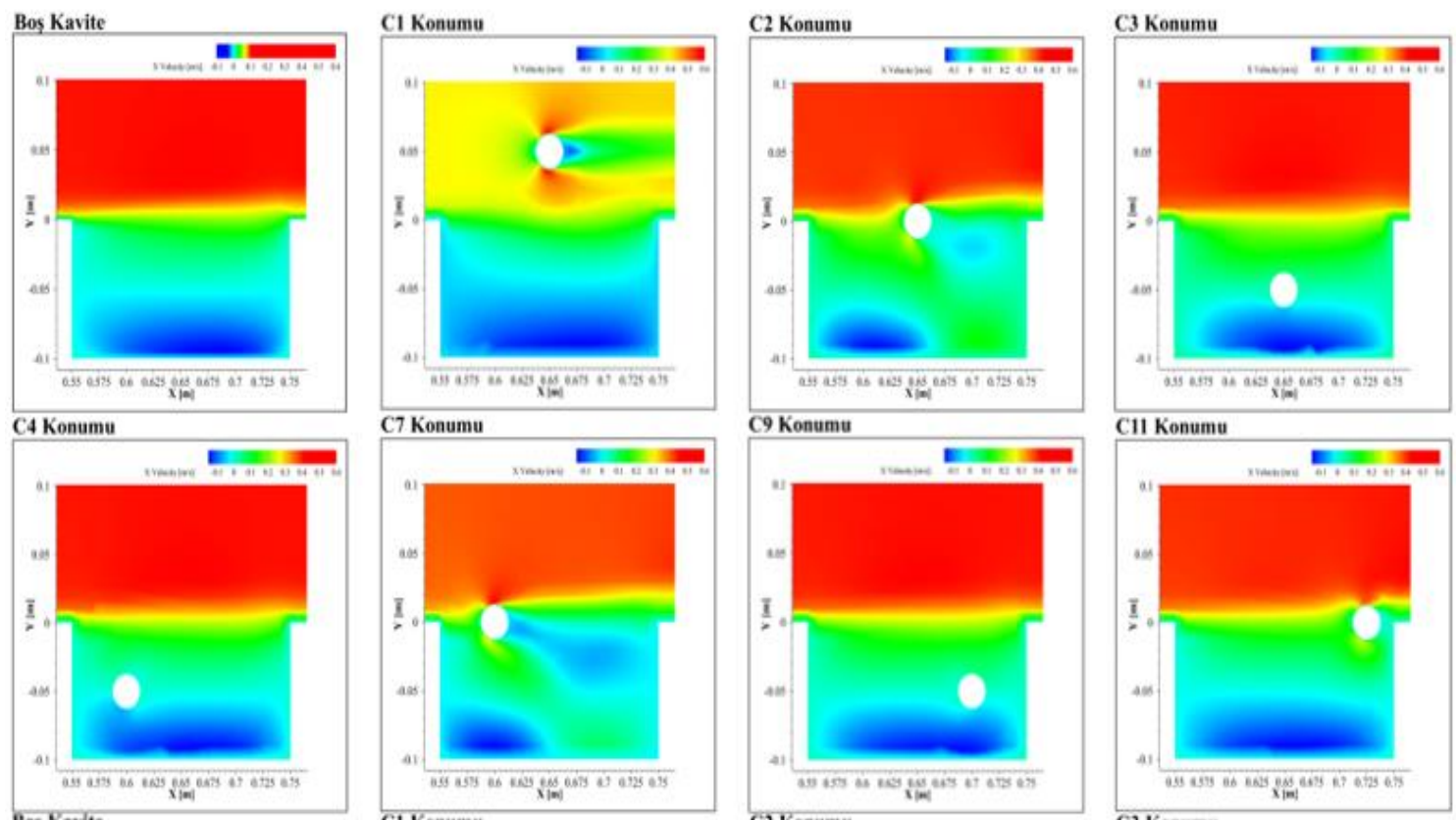

Bes Kavite
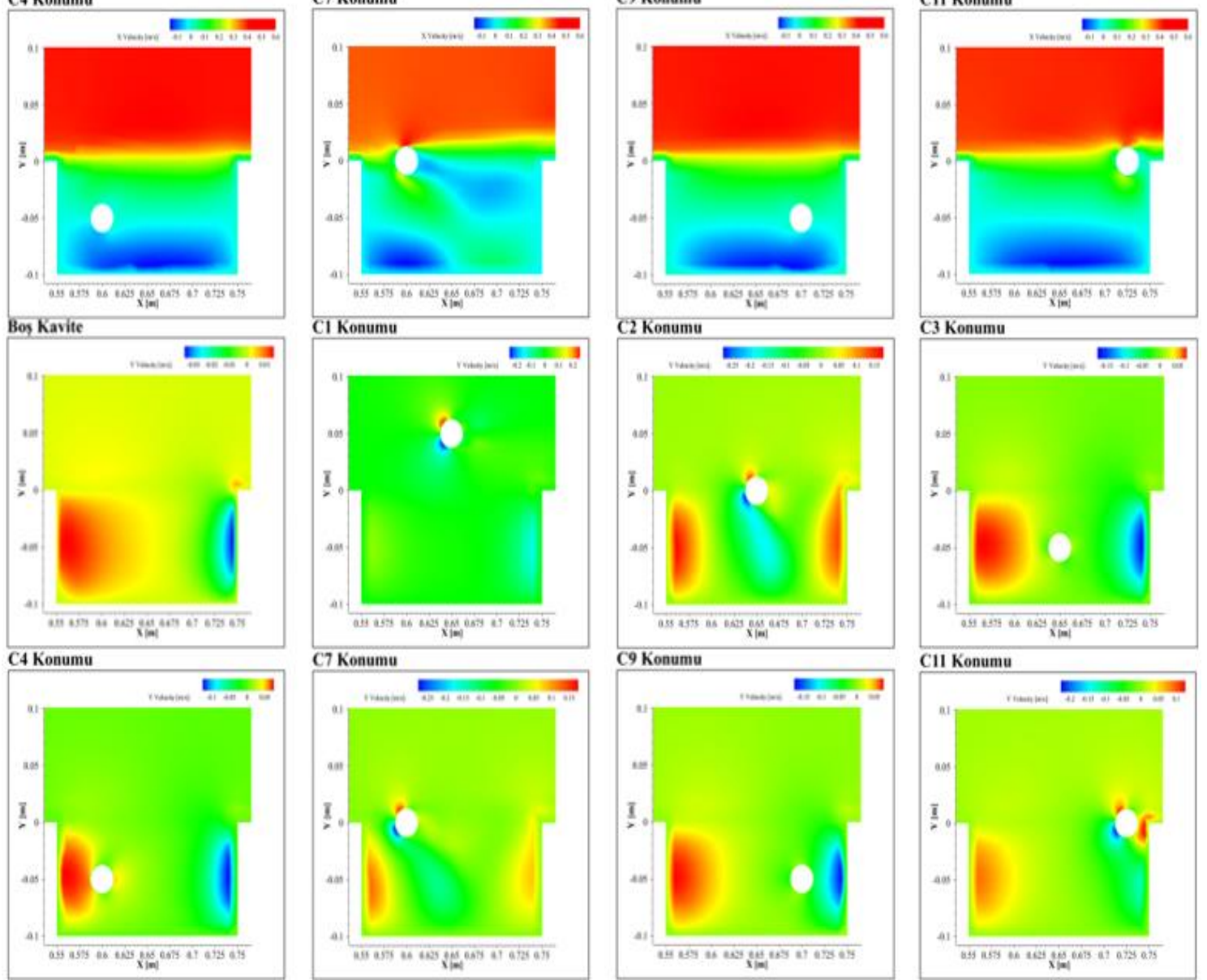

Şekil 5. Değișen silindir konumlarına göre kavite içindeki x ve y hızı dağılımları 

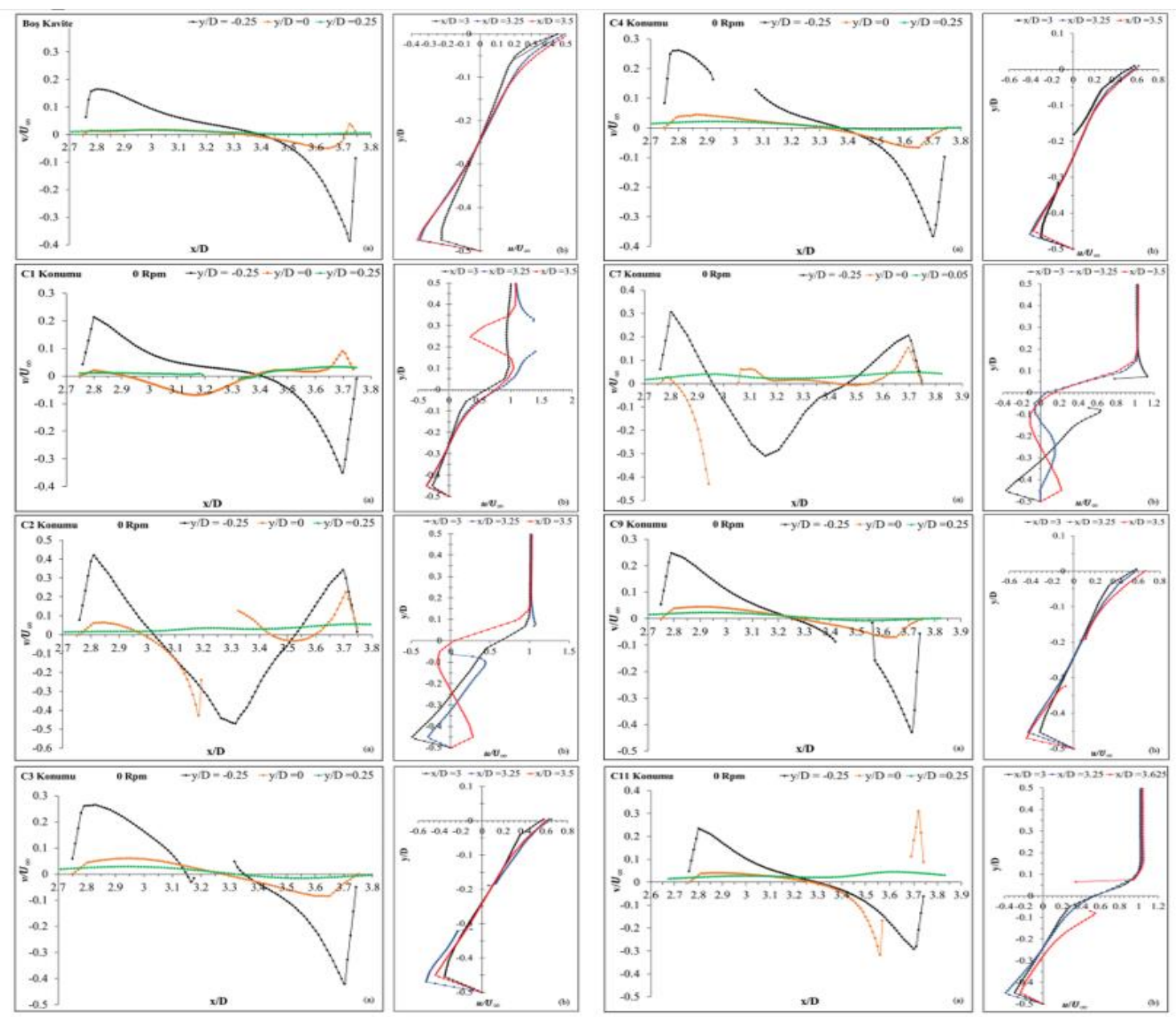

a) Akışa dik doğrultudaki boyutsuz hız profili b) Akış doğrultusundaki boyutsuz hız profili

Şekil 6. Değişen silindir konumlarına göre boyutsuz hız profilleri

$u / U_{\infty}$ ve $\mathrm{v} / U_{\infty}$ hız profillerini gösteren grafik eğrilerindeki kopmalar, hız bileşenlerinin silindir üzerinde tanımlanmasından kaynaklanmaktadır. Akışa dik doğrultudaki ve akış doğrultusundaki hız bileşenlerinin oluşturduğu pozitif ve negatif tepe değerleri kavite içerisindeki girdap yapılarını ve oluşan ters akışı göstermektedir. Boş kavite, C1, C4, C9 ve C11 konumlarında $\mathrm{y} / \mathrm{D}=-0,25$ 'teki hız profillerinin $\mathrm{x} / \mathrm{D}=3,7$ ile $\mathrm{x} / \mathrm{D}=3,8$ aralıklarında hızdaki negatif tepe değerleri Şekil 6' da gösterilen kavite arka duvarı ile etkileşen kayma tabakasının oluşturduğu saat yönündeki girdap yapılarıdır. Boş kavite akışındaki bu tepe değerinin $\mathrm{C} 1$ konumu için $\mathrm{x} / \mathrm{D}=3,6$ 'ya doğru gerilediği belirlenmiştir. $\mathrm{Bu}$ durum girdap boyutundaki azalmadan kaynaklanmaktadır. $\mathrm{x} / \mathrm{D}=3,5$ 'teki hız profilinin kavite tabanına yakın konumlarda oluşturduğu ters akışın C1 konumu için daha yüksek hız büyüklüklerinde olduğu görülmektedir.

Dalgalanmaların en fazla olduğu $\mathrm{C} 2$ ve $\mathrm{C} 7$ konumlarında $\mathrm{x} / \mathrm{D}=3$ 'teki hiz profilinde negatif yöndeki hız artışı kavite ön duvarına ve kavite tabanına yakın konumda oluşan birinci ters akışı, $\mathrm{x} / \mathrm{D}=3,5$ 'teki hız profilinin kavite tabanına doğru pozitif yönde değişimi silindirin alt yüzeyinde kayma tabakasına ait ikinci ters akışın varlığını göstermektedir. $y / D=-0,25$ 'teki negatif ve pozitif 
tepe değerinden, bahsedilen ters akışların saat yönünde birincil girdap ve saat yönünün tersi yönündeki ikincil girdap yapıları oldukları belirlenmiştir. Benzer salınıma kayma tabakası doğrultusundaki hız bileşenlerinde de rastlanmıştır ve $\mathrm{y} / \mathrm{D}=0$ 'daki hız bileşeninin negatif yöndeki eğimi silindirin arka yüzeyinde bulunan ve saat yönünde dönen üçüncü girdap akışını temsil etmektedir. İki konumun akış yapıları her ne kadar benzer özellikte olsa da kavite tabanına yakın konumlarda oluşturdukları hı büyüklükleri açısından C2 konumu daha güçlü ters akış yapıları meydana getirmiştir. C3 konumunda, $y / D=-$ 0,25 'teki hız profiline ait eğri parçaları üzerinde iki negatif tepe noktasının olması silindirin ön ve arka yüzeylerinde aynı yönde dönen iki girdap akışının olduğunu göstermektedir. C4 ve C9 konumlarında silindiri de içerisine alan ana girdap yapılarının hız büyüklüklerine bağlı oluşturduğu ters akış yapıları her iki konum için fark edilir sonuçlar ortaya koymuştur. $\mathrm{Bu}$ yüzden $\mathrm{C} 4$ ve $\mathrm{C} 9$ konumlarının akış doğrultusundaki hı büyüklükleri karşılaştırıldığında, C9 konumunun kavite ön duvarına doğru daha büyük negatif hızlara sahip olduğu gözlemlenmiştir. Kavite arka duvarına yakın ve kayma tabakası doğrultusundaki C11 konumunda ana girdabın oluşturduğu tepe değeri haricinde $\mathrm{y} / \mathrm{D}=0$ konumundaki hız bileşeni için iki ayrı tepe değeri daha belirlenmiştir. $\mathrm{Bu}$ tepe noktaları silindir etrafındaki kayma tabakasının kavite içerisine yönelen ve silindirin alt yüzeyinden ayrılan akışın hız büyüklükleri göstermektedir.

\subsubsection{Akış Alanındaki Akım Çizgileri}

Değişen silindir konumlarına göre çizilen akım çizgileri Şekil 7'de gösterilmiştir. Boş kavite durumunda kavite ön duvarından ayrılan kayma tabakası, kavite arka duvarı ile etkileşime girerek ana girdap yapısının şekillenmesini sağlamıştır. Ana girdap ile kavite ön duvarının en alt noktasında ters yönde dönen köşe girdabı oluşumu beklenirken, akış enerjisinin çoğunu içinde barındıran ana girdap, tüm kavite uzunluğunu kapladığından ikinci bir girdap gelişimine izin vermemiştir. C1 konumunda kaviteye gelen akış ilk olarak silindirin ön yüzeyiyle temas ederek, Reynolds sayıs 5 ile 40 aralığında oluşan Durgun Föppl Girdap yapısına benzeyen silindir etrafında akış oluşturmuştur
Lienhard [19]. Silindirin alt yüzeyindeki hız artış1 kavite içerisine doğru bir dereceye kadar salınım oluşturan kayma tabakasının, kavite arka duvarına yakın saat yönü doğrultusunda dönen ana girdap yapısının oluşmasını sağlamıştır. Ana girdap, boş kavitedeki girdap yapısına benzer yönde dönen girdap akışı olmasına rağmen boyut olarak daha küçük bir yapıya sahiptir. C2 konumunda kayma tabakasındaki kararsızlığın artması, kavite tabanına yakın iki ana girdap ve silindirin arka yüzeyinde üçüncü bir girdap yapısını oluşturmuştur. Ana girdapların ilki kavite ön duvarına yakın konumda ve saat yönü ile aynı doğrultuda, ikincisi ise kavite arka duvarına yakın ve saat yönünün tersi yönde dönen girdap yapılarıdır. Üçüncü girdap yapısı ikinci ana girdaptan meydana gelmiştir ve birinci ana girdap ile aynı yönde dönmektedir. İkinci ve üçüncü girdap yapılarının kavite içerisinden uzaklaşmak isteyen akışın hareketini olumlu yönde etkilediği görülmektedir. C3 konumu, C2 konumu kadar kayma tabakasında salınım oluşturmasa da kavite içerisindeki ters akışı güçlendirecek iki ana girdap yapısı oluşturmuştur. Saat yönünde dönen bu girdapların, kavite arka duvarı ile etkileşime geçen kayma tabakasının oluşturduğu ters akışın girdap çekirdeğine yakın silindirin ön ve arka yüzeylerindeki akış ayrılmasından meydana gelmiştir. C4 konumunda boş kaviteye benzer şekilde silindiri içerisine alan ve saat yönünde dönen ana girdap yapısının oluştuğu gözlemlenmiştir. Silindir etrafındaki akışın bir kısmı ön duvara yakın konumda kavite içerisinden uzaklaşırken diğer bir kısmı silindirin arka yüzeyindeki girdap çekirdeğinin oluşmasını sağlamıştır. C7 konumu silindirin alt yüzeyinden geçen kayma tabakasının kavite tabanına yakın iki ana girdap ve ikinci girdap yapısından oluşan silindirin arka yüzeyinde üçüncü ve dördüncü girdap yapılarını oluşturmuştur. Birincil girdap kavite ön duvarına yakın ve saat yönünde, ikinci girdap ise kavite arka duvarına yakın ve saat yönünün tersi yönde dönmektedir. Üçüncü girdap olarak bahsedilen silindirin arka yüzeyinde oluşan girdap yapısı, ikinci girdap ile aynı yöndedir. Silindirin üst yüzeyinden geçen kayma tabakası ile ikinci girdap yapısının etkileşimi sonucunda oluşan dördüncü girdap yapısı saat yönünde dönmektedir. C9 ve C4 konumları benzer akış yapıları oluşturmalarına rağmen $\mathrm{C} 9$ konumunda silindirin 
arka yüzeyinde oluşan girdap çekirdeğinin küçüldüğü ve girdap boyutunun arttığı belirlenmiştir. Kavite arka duvarına yakın olan C11 konumu tüm kaviteyi kaplayan ve saat yönünde dönen ana girdap ile kaviteden uzaklaşmak isteyen
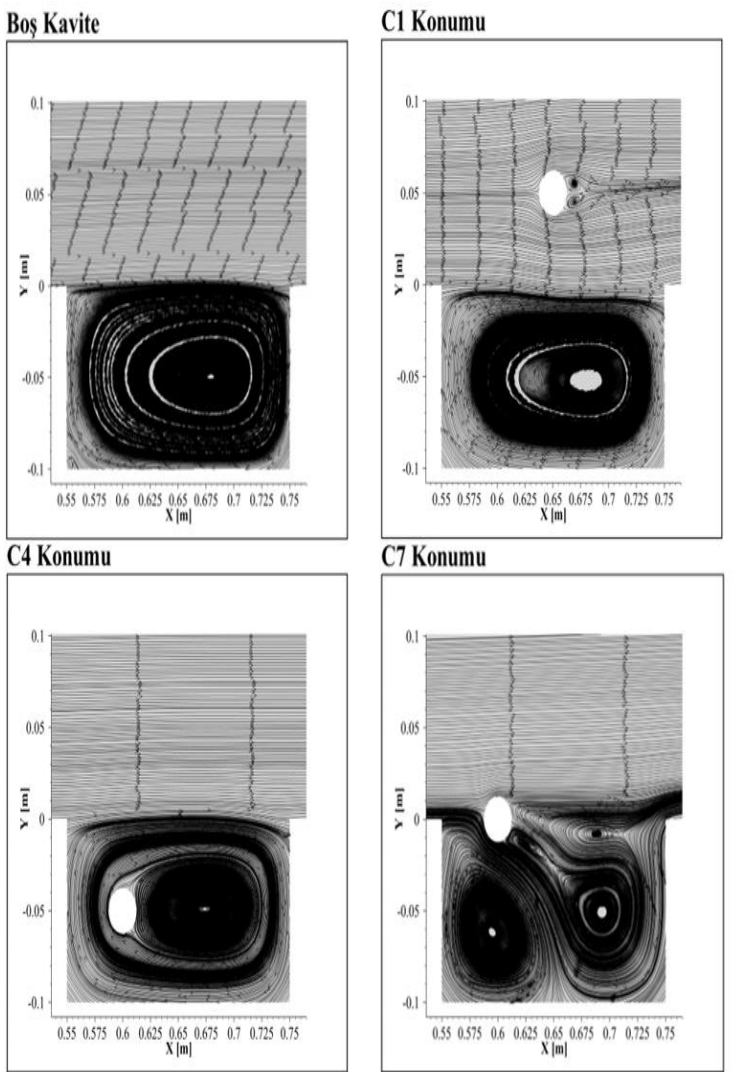

Şekil 7. Değişen silindir konumlarına göre kavite içindeki akım çizgileri

\subsubsection{Akış Alanındaki Girdap Dağılımları}

Farklı silindir konumlarının kavite içerisinde oluşturdukları girdap dağılımları Şekil 8'de gösterilmiştir. Kavite orta düzleminde farklı konumlara yerleştirilen silindirin meydana getirdiği girdaplar özellikle $\mathrm{C} 1$ ve $\mathrm{C} 2$ konumlarında oldukça belirgindir. $\mathrm{C} 1$ ve $\mathrm{C} 2$ konumlarındaki girdaplar, gelen akışın silindir etrafında akış alanı oluşturduğu bölgelerde ve bunun haricinde $\mathrm{C} 2$ konumunda kavite içerisindeki kayma tabakası kararsızlıklarının artışına bağlı oluşan girdap yapılarında gözlemlenmiştir. akışın hızını arttırmıștır. Silindirin kavite orta düzleminde ve kayma tabakası doğrultusunda olmasının boş kavitedeki akış yapısını değiştirerek girdap sayısında belirgin bir artışın oluştuğu saptanmıştır.
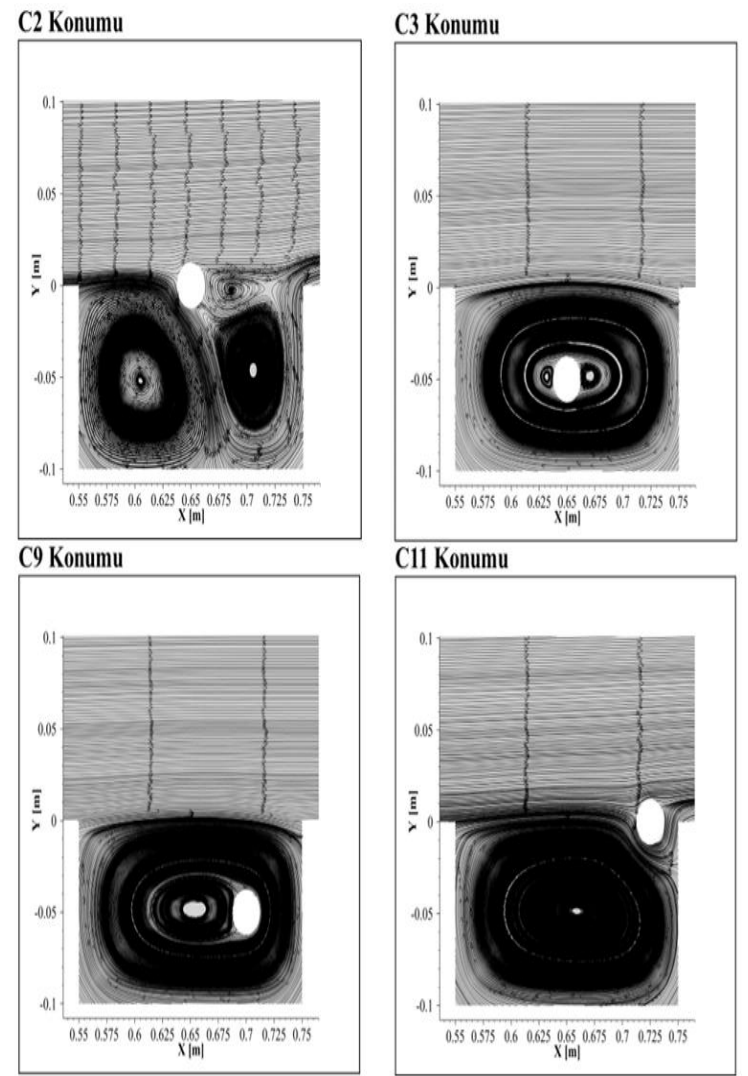

Benzer akış yapısına sahip C7 konumunun Şekil 7'deki akım çizgilerine bakıldığında kavitedeki girdap yapılarının varlığı aynı şekilde girdap dağılımları için elde edilmemiştir. Bunun nedeni olarak ise silindirin etrafında oluşan akışın kavite içerisindeki akıştan daha türbülanslı olmasından kaynaklandığ 1 düşünülmektedir. C3, C4, C9 ve C11 konumlarında girdap üretimi silindir etrafındaki akış için türbülanslı iken kavite içerisinde yeterli hareketlilik sağlanamamıştır. Kavite içerisindeki durgun akışta yeteri kadar hareketliliğin sağlanamadığı boş kavite akışına nispeten kavite içerisindeki silindirin, akışta belirgin girdap dağılımları oluşturduğu görülmektedir. 

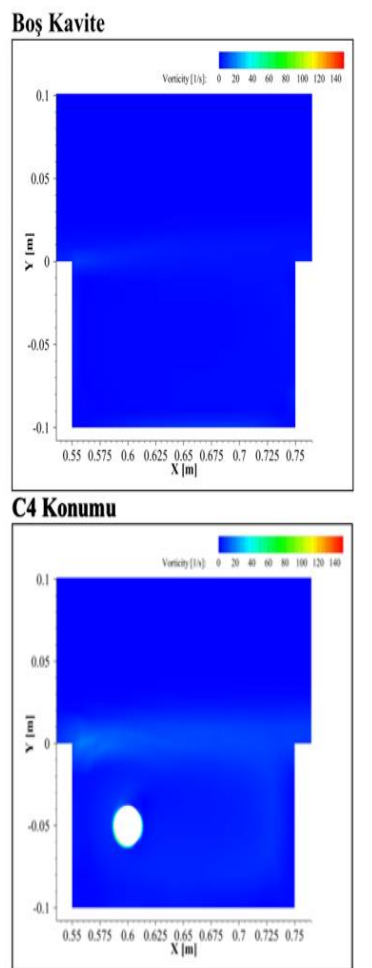
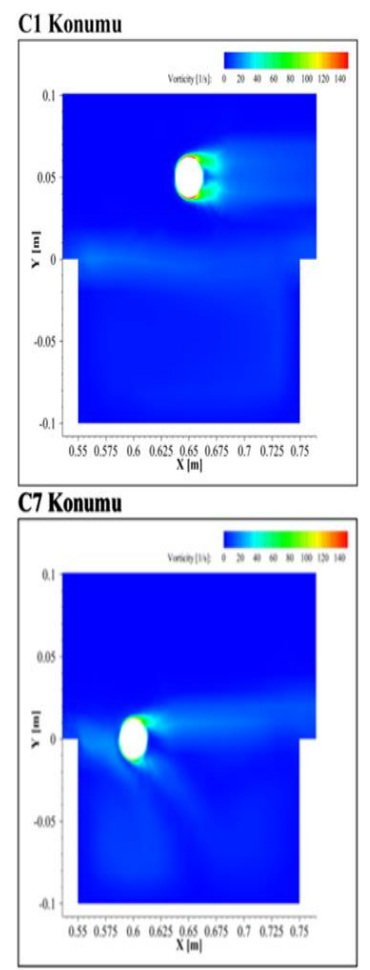
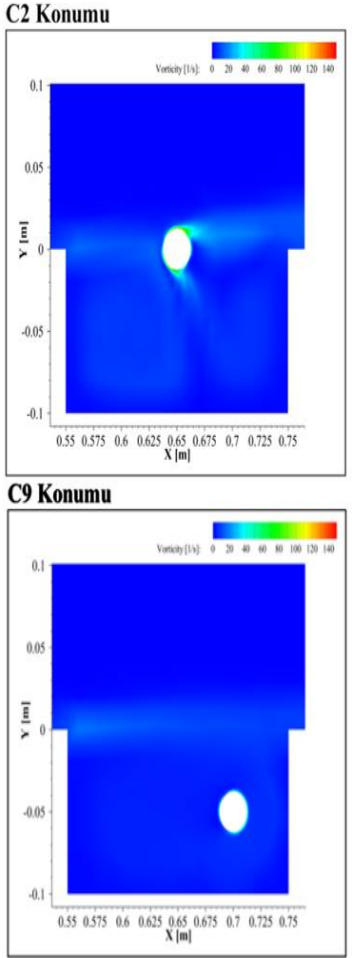
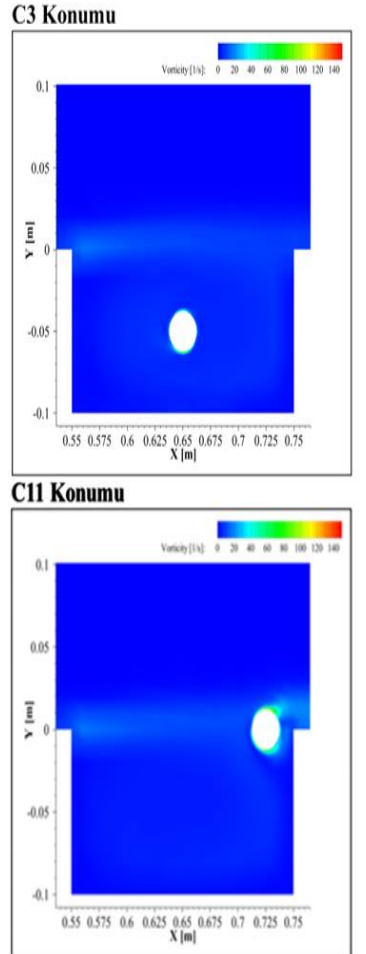

Şekil 8. Değişen silindir konumlarına göre kavite içindeki girdap dağılımları

\subsection{Silindir Konumlarının Isı Transferi Üzerindeki Etkisi}

Kavite duvarlarına sabit $1 \mathrm{~s} 1$ akıs $\left(\dot{\mathrm{q}}=10000 \mathrm{~W} / \mathrm{m}^{2}\right)$ uygulanmış açı kavite içerisine yerleştirilen silindirin 1S1 transferi üzerindeki etkisi sicaklık dağılımlarının (Şekil 9) ve Nusselt sayısının (Şekil 10) değișimi ile gösterilmiștir. C1 konumunda kavite ön duvarından ayrilarak silindirin alt yüzeyinden geçen akışın yüksek hızlarda kavite tabanına yeniden bağlanması ve ana girdap yapısının boyutundaki azalma 1sı transferini boş kaviteye nispeten iyileştirmiştir. Her iki durumun sıcaklık dağılımları incelendiğinde, bu etki $\mathrm{C} 1$ konumunda kavite içerisindeki sıcaklık farkının azalmasından açıkça görülmektedir. Silindirin alt ve arka yüzeyinde oluşan ikinci ve üçüncü girdaplar (Şekil 7) C2 konumunda, ısınan akışın kavite içerisinden uzaklaştırılmasında etkili olmuştur. Bu yüzden kavite arka duvarına yakın konumlarda fark edilir derecede sıcaklık dağılımlarında azalmalar mevcuttur. C3 konumunda silindirin ön ve arka yüzeylerindeki aynı yönde dönen girdap akışları, kavite ön duvarı ile etkileşime geçen akışın bir kısmını kaviteden uzaklaştırmış, bir kısmını ise tekrar kavite içerisine almıştır. Bu durum ısınan akışın tekrar kavite içerisinde hapsolmasından dolayı C1 ve C2 konumlarına göre kavite içerisindeki sıcaklık farkı artmıștır. C4 ve C9 konumlarında kayma tabakasının silindiri de içerisine alarak oluşturduğu girdapların ve girdap çekirdeklerinin boyutları her iki konum için farklı sonuçlar sağlamıştır. C9 konumunun girdap boyutunun artırması ve silindirin ön yüzeyindeki girdap çekirdeğinin küçük boyutta oluşması $\mathrm{C} 4$ konumuna göre kavite içerisindeki sıcaklık farkını azaltmıştır. $\mathrm{Bu}$ durum kavite alt duvarına yeniden bağlanan ve ısıtılmış kavite duvarlarıyla etkileşen akışın kaviteden uzaklaşmasını kolaylaştırarak 1S1 transferini olumlu yönde etkilemiştir. C4 konumunun küçük boyutta girdap yapısına ve büyük bir girdap çekirdeğine sahip olması boş kavite akışından daha düşük 1sı transfer sonuçları ortaya çıkarmıştır. 

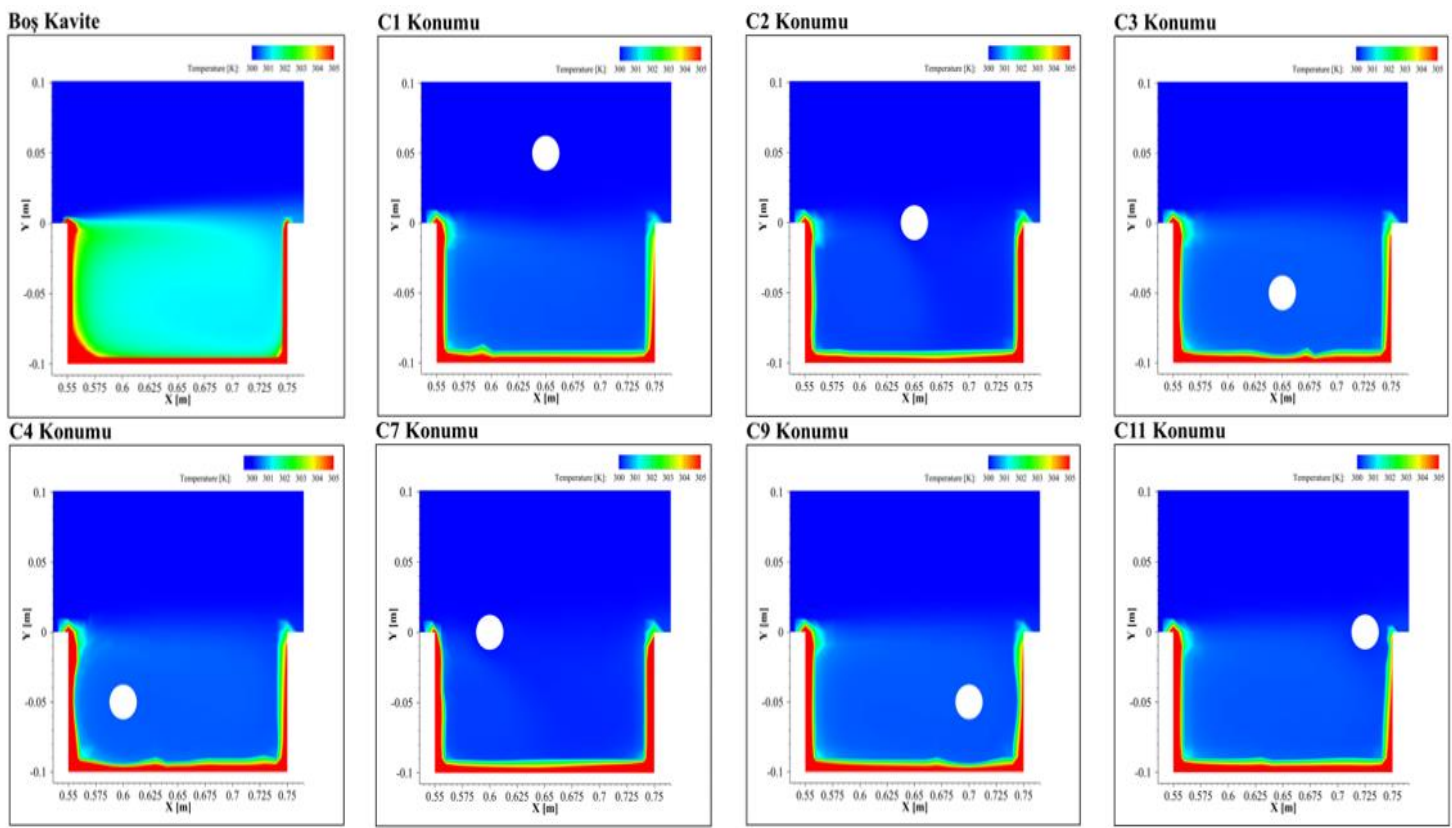

Şekil 9. Değişen silindir konumlarına göre kavite içindeki sıcaklık dağılımları

C7 konumunda, ikinci girdap yapısına ilaveten silindirin arka yüzeyindeki üçüncü bir girdabın varlığı, kavite arka duvarına yakın konumlarda yüzey sıcaklığını artırmıştır. Bu girdap yapısının ısınan akışı tekrar kavite akışına eklemesi kavite içerisindeki sıcaklık farkını artırırken beraberinde 1S1 transfer kalitesini düşürmüştür. C11 konumu tüm kavite yüzeyi boyunca tek bir girdap akış1 oluşturmasına rağmen silindirin alt yüzeyinden geçen akışın yüksek hızlarda yeniden bağlanması, kaviteden akışın daha kolay uzaklaştırılmasını sağlamıştır. Tüm kavite yüzeyi boyunca tek bir girdap akışının oluşması boş kavite akışına nispeten 1sı transferini iyileştirmiştir.

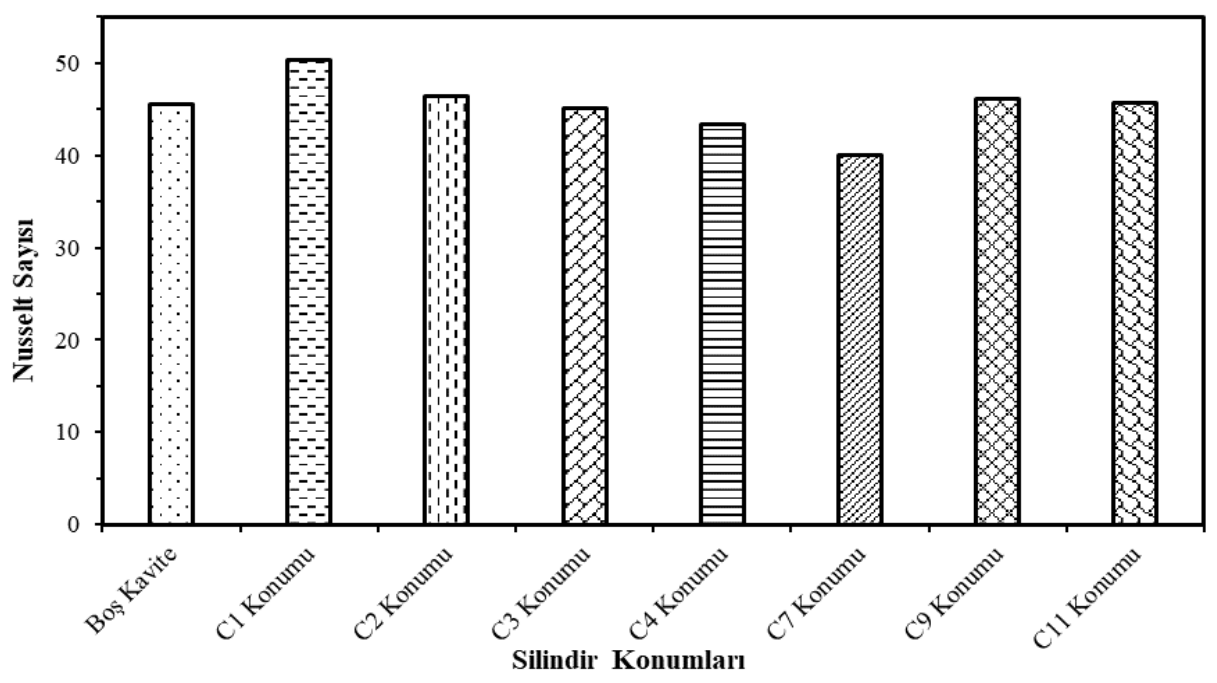

Şekil 10. Boş kavite ve silindir konumlarına göre Nusselt sayısının değişimleri 
Boş kavitenin ve silindir konumlarına göre Nusselt sayısının değişim grafiği Şekil 10'da gösterilmiştir. Boş kavitede ayrılan akışın 1sıtılmış kavite alt yüzeyine tekrar bağlanmasıyla oluşan ana girdap yapısının, ısınan akışın büyük bir kısmını kaviteden uzaklaştıracak enerjide olmaması kavite içerisindeki sıcaklık farkını artırmıştır. Silindir konumları, bu noktada oluşturduğu girdap akışları ile yüzey sıcaklığı ile akışkan sıcaklığı arasındaki sıcaklık farkının azaltılmasına yönelik etkiler sağlamışlardır. Yüksek enerjili girdap yapılarının oluştuğu ve kavitede yüzey sıcaklığını azalmasının sağlandığı C1, C2, C9 ve C11 silindir konumları boş kavite akışına göre 1sı geçişini iyileştirmiştir. Benzer akış yapılarının gözlemlendiği C4 ile C9 ve C2 ile C7 konumlarında kavite içerisindeki girdap oluşumlarına göre 1 sı geçişi açısından farklı sonuçlar elde edilmiştir. $\mathrm{Bu}$ durumun, 1sıtılmış kavite yüzeylerindeki 1sı transfer özelliklerinin, ayrılmış akışın yeniden bağlanması, girdap yapısından büyük ölçüde etkilendiğini göstermektedir.

\section{SONUÇLAR}

Bir adyabatik dairesel silindirin iki boyutlu açık kavite içerisinde 7 farklı konuma $(\mathrm{C} 1, \mathrm{C} 2, \mathrm{C} 3, \mathrm{C} 4$, C7, C9 ve C11 silindir konumları) yerleştirilmesinin akış yapısı ve 1sı transfer üzerindeki etkileri sayısal olarak incelenmiştir. Açık kavitenin uzunluk/derinlik oranı 2'dir ve silindir çapı ile tanımlanan Reynolds sayısı 10000 olarak belirlenmiştir. İki boyutlu, zamana bağlı sıkıştırılamaz akış için sonlu hacimler yöntemine dayalı çözümleme kullanılmıştır. Bu çalışmanın ana sonuçları şu şekilde özetlenebilir;

- Boş kavite akışındaki tüm kavite yüzeyini kaplayan zayıf girdap akışının yerine ısıtılmış yüzeylere temas eden yüksek hızlarda girdap akışının oluşması ısı geçişini arttırmıştır. C1, C9 ve $\mathrm{C} 11$ konumları kavite uzunluğu boyunca oluşturdukları yüksek hızlardaki girdap yapıları ile ısı transferinde iyileştirme sağlamışlardır.

- Kayma tabakasında oluşan salınımların artışı kavite içerisindeki girdap yapılarının artmasında etkili olmuştur. C2 konumda kavite arka duvarına yakın ve silindirin arka yüzeyindeki girdap akışları ısınan akışın uzaklaştırılmasını sağlayarak kavite içerisindeki sıcaklık farkını azalmıştır. C7 konumunda ise C2 konumdan farklı olarak silindirin alt yüzeyinde ilaveten üçüncü girdap akışının oluşması 1sı geçişi için olumsuz bir şekilde etkilemiştir.

- C4 ve C9 konumları benzer akış yapıları oluşturmalarına rağmen $\mathrm{C} 4$ konumunda düşük 1s1 transfer sonucu elde edilmiştir. $\mathrm{Bu}$ durum silindirin arka yüzeyinde oluşan resirkülasyon bölgesinin boyutundaki artıştan kaynaklanmıştır. $\mathrm{Bu}$ resirkülasyon bölgesi ısınan akışı tekrar kavite içerisinde dolaştırarak 1S1 geçiş kalitesinin düşmesine sebep olmuştur. Aynı şekilde C3 konumu da silindirin ön ve arka yüzeylerinde iki resirkülasyon bölgesi oluşturmuştur ve benzer sonuç bu konum içinde gözlemlenmiştir.

\section{KAYNAKLAR}

1. Güleren, M.K., Çelik, B., Demir, O., 2018. Transonik Akışlarda Girdap Üreteçlerinin Kavite Gürültüsüne Etkisi, VII Ulusal Havacılık ve Uzay Konferans1, 117, Ondokuz Mayıs Üniversitesi Samsun-Türkiye, 12-14 Eylül.

2. Charwat, A., Roos, R., Dewey, F., Hitz, Jr, J., 1961. An Investigation of Separated Flows-part I: The Pressure Field, Journal of the Aerospace Sciences, 28: 457-470.

3. Ahuja, K., Mendoza, J., 1995. Effects of Cavity Dimensions, Boundary Layer, and Temperature on Cavity Noise with Emphasis on Benchmark Data to Validate Computational Aeroacoustic Codes, NASA Contrat Report, 4653.

4. Haugen, R., Dhanak, A., 1967. Heat Transfer in Turbulent Boundary-Layer Separation Over a Surface Cavity, J. Heat Transfer 89, 335-340.

5. Yamamoto, H., Seki, N., Fukusako, S., 1979. Forced Convection Heat Transfer on Heated Bottom Surface of a Cavity, J. Heat Transfer, 101, 475-479.

6. Pereira, J., Sousa, J., 1995. Experimental and Numerical Investigation of Flow Oscillations in a Rectangular Cavity, Journal of Fluids Engineerin, 117, 68-73 
7. Zdanski, P., Ortega, M., Fico, N.G., Jr, 2003. Numerical Study of the Flow Over Shallow Cavities, Computers and fluids, 32, 953-974.

8. Ashcroft, G., Zhang, X., 2005. Vortical Structures Over Rectangular Cavities at Low Speed, Physics of Fluids, 17, 015104.

9. Faure, T.M., Adrianos, P., Lusseyran, F., Pastur, L., 2007. Visualizations of the Flow Inside an Open Cavity at Medium Range Reynolds Numbers, Experiments in Fluids, 42,169-184.

10. Kang, W., Sung, H.J., 2009. Large-Scale Structures of Turbulent Flows Over an Open Cavity, Journal of fluids and structures, 25, 1318-1333.

11. Ozalp, C., Pinarbasi, A., Sahin, B., 2010. Experimental Measurement of Flow Past Cavities of Different Shapes, Experimental Thermal and Fluid Science, 34, 505-515.

12. Özsoy, E., Aslan, A.R., 2011. Üç Boyutlu Bir Kavite Üzerindeki Sıkıştırılamaz Akışın Sayısal Bir Yöntemle Analizi, İTÜ Dergisi Mühendislik, 10(3), 149-159.

13. Wahba, E., 2014. On the Steady Flow in a Rectangular Cavity at Large Reynolds Numbers: A Numerical and Analytical Study, European Journal of Mechanics-B/Fluids, 44, 69-81.

14. Chen, H., Zhong, Q, Wang, X., Li, D., 2014. Reynolds Number Dependence of Flow Past a Shallow Open Cavity, Science China Technological Sciences. 57, 2161-2171.

15. Selimefendigil, F., Öztop, H.F., 2014. Numerical Study of MHD Mixed Convection in a Nanofluid Filled Lid Driven Square Enclosure With a Rotating Cylinder, International Journal of Heat and Mass Transfer, 78, 741-754.

16. Madi, A.F., 2016. Heat Transfer Prediction in a Shallow Cavity Effect of Incoming Flow Characteristics, Thermal Science, 20, 1519-1532.

17. Doğan, F.B., 2014. Eş Merkezli Dönen İki Silindir Arasında Oluşan Taylor ve Von Karman Vortekslerinin Hesaplamalı Akışkanlar Dinamiği ile İncelenmesi, TOBB Ekonomi ve Teknoloji Üniversitesi, Fen Bilimleri Enstitüsü, Yüksek Lisans Tezi, Ankara, 126.

18. Çengel, Y., Cimbala, J., 2012. Akışkanlar Mekaniği Temelleri ve Uygulamaları (2. Basım), İzmir: İzmir Güven Kitabevi.
19. Lienhard, J.H., 1966. Synopsis of Lift, Drag, and Vortex Frequency Data for Rigid Circular Cylinders, Technical Extension Service, Washington State University Pullman, WA. 
